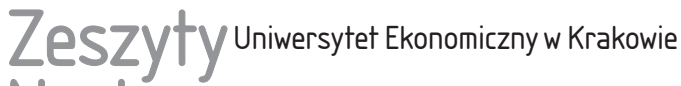 Naukowe
}

\section{Źródła finansowania rozwoju przez jednostki samorządu terytorialnego}

\section{Streszczenie}

Jednym z najważniejszych obszarów zarządczych związanych z kreowaniem rozwoju jest zapewnienie źródeł finansowania. Wymaga to efektywności w bieżącym zarządzaniu dostępnymi środkami, a także umiejętności pozyskiwania najtańszego finansowania zewnętrznego. Istotne bariery finansowego zasilania jednostek samorządu terytorialnego determinują poszukiwanie alternatywnych źródeł finansowania inwestycji w formie kredytów, pożyczek czy emisji papierów wartościowych. Zmiany dokonujące się w otoczeniu w różny sposób wpływają na sytuację finansową samorządu, a tym samym mają bezpośredni wpływ na możliwości finansowania rozwoju.

Celem artykułu jest analiza źródeł finansowania rozwoju przez samorząd terytorialny. Okres badawczy obejmuje lata 2012-2016, co pozwoliło na ocenę tendencji zmian analizowanych miar i kategorii w czasie.

Słowa kluczowe: rozwój lokalny, rozwój regionalny, samorząd, źródła finansowania rozwoju.

Klasyfikacja JEL: H71, H72, H74.

\section{Wprowadzenie}

W polityce Unii Europejskiej, ale również Polski, polityka rozwojowa zajmuje ważne miejsce. Za jej sprawą władze krajowe i lokalne są mobilizowane do bardzo 
poważnego traktowania zagadnień rozwoju lokalnego i regionalnego. Niewątpliwie jednym z najważniejszych obszarów zarządczych związanych z kreowaniem rozwoju jest zapewnienie źródeł finansowania. Racjonalne gospodarowanie funduszami publicznymi, tak aby maksymalnie zaspokajać potrzeby społeczności lokalnej, a jednocześnie w jak najbardziej optymalny sposób oddziaływać na rozwój lokalny czy regionalny, wymaga nie tylko bieżącego efektywnego zarządzania dostępnymi środkami, ale też efektywnego, czyli najtańszego pozyskiwania finansowania zewnętrznego. Duże znaczenie ma dostęp do źródeł finansowania, w tym środków unijnych, a także stabilność tych źródeł.

Przez finansowanie rozwoju należy rozumieć wydatki ponoszone przez JST w celu osiągania pożądanych zmian w życiu społecznym i gospodarczym, w tym przede wszystkim wydatki na inwestycje, tj. tworzenie majątku, jego ulepszenie czy modernizację. Każdy samorząd prowadzi własną politykę rozwoju, której realizacja wymaga zabezpieczenia odpowiednich środków finansowych. Do głównych źródeł finansowania rozwoju należy zaliczyć środki własne JST, dotacje oraz zobowiązania. Zmiany dokonujące się w otoczeniu mogą mieć różnoraki wpływ na sytuację finansową samorządu, a tym samym bezpośredni wpływ na możliwości finansowania rozwoju.

Celem artykułu jest przedstawienie możliwości wykorzystania dostępnych źródeł finansowania rozwoju lokalnego i regionalnego przez JST, w szczególności przedstawienie głównych źródeł finansowania, takich jak: dochody własne, dotacje i subwencje, a także wskazanie roli i znaczenia zewnętrznego finansowania rozwoju, głównie przez kredyty, pożyczki czy emisję papierów wartościowych.

Jako metodę badawczą zastosowano krytyczną analizę literatury oraz aktów normatywnych z zakresu finansów publicznych. W opracowaniu wykorzystano grupę metod typowych dla nauk społecznych, jakimi są metody poznania empirycznego, w szczególności obserwacja, porównanie i pomiar, którego dokonano dla lat 2012-2016.

Celem przeprowadzonych badań i studiów jest wskazanie możliwości wspierania rozwoju przez samorząd zarówno z wykorzystaniem środków własnych, jak i zwrotnych źródeł finansowania. Zasadnicza teza opracowania zawiera się w stwierdzeniu, że wykorzystywanie zewnętrznych źródeł finansowania rozwoju, chociaż zwiększa deficyt i dług, a także koszty ich obsługi, wpływa korzystnie na rozwój lokalny czy regionalny.

\section{Pojęcia rozwoju lokalnego i regionalnego}

Podstawowym celem wydatków publicznych dokonywanych przez JST jest zaspokajanie potrzeb społecznych, w tym wynikających z rozwoju lokalnego lub 
regionalnego. Pojęcie rozwoju lokalnego najczęściej oznacza określanie pożądanych kierunków zmian w życiu społecznym i gospodarczym w skali lokalnej. Określenie „lokalny” oznacza charakterystyczny dla danego miejsca, ograniczony, zawężony do danego obszaru, miejscowy (Gałuszka 2005). Natomiast przez „rozwój” najczęściej rozumie się proces zmian prowadzący do ulepszenia czegoś, zwiększenia czegoś, osiągnięcia poziomu pod jakimś względem wyższego. Konieczne jest zatem doprecyzowanie zarówno przedmiotu, jak i podmiotu rozwoju.

Podejście przedmiotowe do rozwoju kładzie nacisk na określenie dziedzin życia społecznego i gospodarczego społeczności lokalnych, w których zmiany jakościowe i ilościowe decydują o uznaniu, czy mamy do czynienia z rozwojem, stagnacją czy regresem. W podejściu podmiotowym główny akcent kładzie się na aktywność społeczności lokalnych jako warunek rozwoju lokalnego (Pietrzyk 2002, s. 32).

W literaturze przedmiotu nie znajdziemy jednoznacznej definicji rozwoju lokalnego. Jedno z proponowanych ujęć koncentruje się na 10 składowych rozwoju lokalnego, wśród których należy wymienić: wzrost gospodarczy i zatrudnienia, wzrost dobrobytu i jakości życia, wzrost atrakcyjności inwestycyjnej, rozwój technologiczny i innowacje, restrukturyzację działalności gospodarczej, rozwój usług i zasobów społecznych, wzrost ruchliwości zawodowej, społecznej i przestrzennej, rozwój infrastruktury instytucjonalnej, polepszenie jakości środowiska, wzbogacenie tożsamości i procesy integracyjne. Rozwój lokalny jest też rozumiany jako rozwój różnych podzespołów miejskich, takich jak: parki nauki i technologii, zespoły małych i średnich firm, nieruchomości miejskie, zaniedbane obszary wewnątrz miast, środowisko mieszkalne, mieszkalnictwo w warunkach ekorozwoju, infrastruktura techniczna środowiska. Powyższe definicje reprezentują podejście przedmiotowe. Podejście podmiotowe natomiast eksponuje przede wszystkich działania podejmowane z woli aktorów (samorządów, podmiotów gospodarczych, stowarzyszeń i innych) na podstawie refleksji dotyczących miejscowych zasobów, uwzględniającej specyfikę terytorialną. Rozwój lokalny oznacza oddolny sposób generowania dynamiki rozwoju, wykorzystujący cały wewnętrzny potencjał rozwojowy w różnej skali przestrzennej, obejmujący zbiorowości terytorialne charakteryzujące się pewną spójnością. Rozwój lokalny to także postawy i zachowania oznaczające gotowość do wzięcia odpowiedzialności za los wspólnoty lokalnej. Wreszcie rozwój lokalny definiowany jest też jako zespół działań mobilizujących lokalnych aktorów wokół uzgodnionych projektów gospodarczych, społecznych, środowiskowych, wynikających ze wspólnie deklarowanej wizji przyszłości danej jednostki lokalnej (por. Pietrzyk 2002). Podejścia przedmiotowe i podmiotowe do rozwoju lokalnego nie są przeciwstawne, kładą jedynie większy nacisk na wybrane aspekty tego pojęcia. 
Ciekawą definicję rozwoju lokalnego, opartą na koncepcji zrównoważonego rozwoju, prezentuje T. Domański (1999, s. 16). Definiuje on rozwój lokalny jako proces stałego wzrostu jakości życia lokalnych społeczeństw, wsparty na wzajemnie zrównoważonych czynnikach o charakterze społecznym, gospodarczym i ekologicznym. Działanie na rzecz zrównoważonego rozwoju powinno być rozumiane jako podejmowanie i wprowadzanie w życie takich decyzji, które na zasadzie kompromisu godzą ze sobą przeciwstawne cele właściwe dla każdej z wymienionych sfer rozwoju. Szczególne miejsce wśród wymienionych sfer rozwoju zajmuje rozwój gospodarczy, który jest siłą napędową procesów rozwojowych w pozostałych sferach. Jego efektem powinien być stały wzrost sprzedaży oraz osiąganego zysku, a w konsekwencji wzrost zamożności i standardu życia mieszkańców. Rozwój społeczny to stały wzrost poziomu wykształcenia mieszkańców, ich świadomości obywatelskiej oraz kultury osobistej. Wyrazem rozwoju społecznego powinien być wzrastający poziom poczucia odpowiedzialności za wspólne sprawy o charakterze publicznym. Z kolei rozwój ekologiczno-przestrzenny wiąże się z poszanowaniem walorów środowiska przyrodniczego oraz starannym kreowaniem ładu przestrzennego na obszarach zurbanizowanych.

Kluczową rolę w kreowaniu rozwoju lokalnego odgrywa samorząd terytorialny. Realizując strategie rozwoju lokalnego czy polityki rozwoju lokalnego, samorząd odzwierciedla interesy społeczności lokalnej, której skład i preferencje podlegają ciągłym zmianom.

Gminy, powiaty czy miasta na prawach powiatu dysponują różnymi instrumentami oddziaływania na rozwój. Z uwagi na tematykę opracowania warto przywołać te, które bezpośrednio wiążą się z zarządzaniem finansami, a więc m.in. budżet, wieloletnie plany inwestycyjne i finansowe, a także politykę finansową. Ta ostatnia jest niezwykle ważna, gdyż stwarza podstawy do realizacji strategii rozwoju i łączy w sobie: politykę dochodową, wydatkową, kształtowanie budżetu, politykę długu, politykę ustalania stawek, cen, czynszów i taryf opłat. Ponadto wśród instrumentów kreowania rozwoju należy wskazać na poziomie lokalnym inwestycje komunalne, realizowane z własnych środków samorządów, inwestycje realizowane w oparciu o zaciągnięty kredyt czy emisje obligacji komunalnych, a także te, które są współfinansowane $\mathrm{z}$ funduszy europejskich lub funduszy celowych.

Za rozwój regionalny odpowiada samorządne województwo. Jednym z największych wyzwań było i jest doprowadzenie do przejrzystego podziału ustrojowej odpowiedzialności za realizację polityki regionalnej pomiędzy władzę samorządową i krajową, aczkolwiek warto podkreślić, że idealny podział nie istnieje.

Rozwój regionalny można rozpatrywać jako rozwój konkretnego regionu lub jako rozwój kraju w jego dekompozycji regionalnej (por. Perło 2004, s. 19). Przez rozwój regionalny można rozumieć zharmonizowane i systematyczne działania społeczności lokalnej, władzy samorządowej oraz pozostałych podmiotów funk- 
cjonujących w regionie, zmierzające do kreowania nowych i poprawy istniejących warunków gospodarki regionu oraz zapewnienia ładu przestrzennego i ekologicznego (Kożuch 2006, s. 177). Zadania samorządu województwa w tym obszarze określa art. 11 Ustawy z dnia 5 czerwca 1998 r. o samorządzie wojewódzkim. Aby prowadzić swoją politykę regionalną, samorząd województwa może wykorzystywać różne instrumenty, wśród których warto wskazać budżet, strategię rozwoju czy politykę inwestycyjną.

\section{3.Źródła finansowania rozwoju}

Finansowanie rozwoju lokalnego czy regionalnego może się odbywać przez różne formy i instrumenty finansowania. Charakter poszczególnych rodzajów dochodów jest wyznaczony przez przepisy prawa. Podstawowym aktem prawnym w tym zakresie jest Ustawa z dnia 13 listopada 2003 r. o dochodach jednostek samorządu terytorialnego. Wśród instrumentów finansowania rozwoju należy wymienić:

- dochody podatkowe,

- dotacje i subwencje,

- dochody niepodatkowe,

- zwrotne źródła finansowania (kredyty, obligacje, papiery wartościowe),

- zobowiązania,

- partnerstwo publiczno-prywatne.

Szczególnym instrumentem wspierana rozwoju, ukierunkowanym na ochronę środowiska oraz rozwój ekologiczny, jest fundusz ochrony środowiska (por. Filipiak i in. 2005, Chojna-Duch i Kornberger-Sokołowska 1999).

Do dochodów podatkowych zalicza się zarówno podatki lokalne, które zostały przypisane gminom, jak i udziały w podatkach stanowiących dochód budżetu państwa, które są źródłem dla wszystkich szczebli samorządu terytorialnego.

Wśród podatków lokalnych zasilających budżety gmin należy wymienić: podatek od nieruchomości, podatek rolny, podatek leśny, podatek od środków transportowych, podatek od działalności gospodarczej osób fizycznych opłacany w postaci karty podatkowej, podatek od spadków i darowizn, podatek od czynności cywilnoprawnych, podatek od psów oraz samoopodatkowanie mieszkańców.

Udziały w podatkach państwowych stanowią dochody dla gmin, powiatów i województw samorządowych. Obejmują one:

- wpływy z podatku dochodowego od osób fizycznych zamieszkałych na terenie danej jednostki samorządu terytorialnego,

- wpływy z podatku dochodowego od osób prawnych i jednostek organizacyjnych nieposiadających osobowości prawnej, mających siedzibę na terenie jednostki samorządu terytorialnego. 
Udział w podatku jest różny dla każdego ze szczebli, ale sposób wyliczania jest ten sam.

Kolejnym źródłem zasilania budżetu samorządów, a tym samym finansowania rozwoju, jest subwencja ogólna, traktowana jako pewna forma transferu środków finansowych z budżetu państwa do budżetów wszystkich jednostek samorządu terytorialnego w celu ich uzupełnienia. Samorządy mają swobodę w dysponowaniu tymi środkami. Subwencję ogólną charakteryzują przede wszystkim: bezzwrotność, nieodpłatność, ogólność, uzupełniający i obiektywny charakter. Subwencja ogólna przysługuje wszystkim jednostkom samorządu terytorialnego. Każdy z rodzajów (części) subwencji (wyrównawcza, równoważąca, regionalna, oświatowa) ma specyficzny, określony ustawowo sposób obliczania.

Dotacje celowe mają charakter uznaniowy. Ich wysokość jest określana w każdym roku w ustawie budżetowej. Są przekazywane JST na ściśle określone cele - zadania do realizacji, w tym w szczególności na realizację zadań z zakresu administracji rządowej oraz innych zadań zleconych, na realizację bieżących zadań własnych JST, czy też na pokrycie częściowe lub w całości kosztów realizacji inwestycji (szerzej por. Filipiak i in. 2005, s. 320). Cechą charakterystyczną dotacji jest to, że podlega zwrotowi, jeżeli została wykorzystana niezgodnie $\mathrm{z}$ przeznaczeniem lub niewykorzystana $\mathrm{w}$ całości. Powinna być też przekazywana zgodnie z zasadą adekwatności, czyli w wysokości zapewniającej realizację zadań zgodnie z przepisami prawa oraz w sposób pozwalający na pełne i terminowe wykonanie tych zadań.

Kolejną kategorię dochodów JST stanowią dochody niepodatkowe, tj. dochody z opłat oraz dochody z mienia.

Opłata ze swej natury jest podobna do podatku. Jest jednostronnym, przymusowym i bezzwrotnym świadczeniem pieniężnym, pobieranym na podstawie prawa i w związku z konkretnymi czynnościami organów państwowych lub samorządowych bądź też za konkretne usługi. Wyróżnia się dwie grupy opłat:

- opłaty za czynności urzędowe,

- opłaty za świadczenie usług (użytkowanie).

Główne rodzaje opłat to: administracyjna, miejscowa, targowiskowa, skarbowa, eksploatacyjna, prolongacyjna, adiacencka, za oddanie nieruchomości w trwały zarząd lub w użytkowanie wieczyste, za zezwolenie na sprzedaż i podawanie napojów alkoholowych. Chociaż tytułów opłat (rodzajowo) jest wiele, to nie stanowią one istotnej pozycji w budżetach JST (por. Misiąg 2004) w przeciwieństwie do dochodów z majątku. Te ostatnie są wyrazem posiadania przez organy publiczne prawa majątkowego, prawa własności. Do kluczowych dochodów majątkowych należą: 
- dochody z wynajmu, dzierżawy i innych umów o podobnym charakterze,

- odsetki i dywidendy oraz wypłaty z zysków z tytułu posiadanych akcji i udziałów w spółkach prawa handlowego, będących własnością lub współwłasnością organów administracji publicznej,

- dochody z przeszacowania wartości majątku na skutek jego rynkowego wzrostu, pochodzące z okresowo wolnych środków finansowych,

- odsetki od pożyczek udzielonych przez JST.

Rozwój lokalny czy regionalny może również być finansowany przychodami, które mają charakter zwrotny, a które zostały zdefiniowane w Ustawie z dnia 27 sierpnia 2009 r. o finansach publicznych. Zgodnie z art. 5 pkt 4 wspomnianej ustawy przychodami publicznymi są wszystkie wpływy niebędące dochodami publicznymi. Do kategorii przychodów publicznych zalicza się w szczególności takie przychody, jak:

- ze sprzedaży papierów wartościowych oraz innych operacji finansowych,

- ze spłat pożyczek udzielonych ze środków publicznych,

- z otrzymanych pożyczek i kredytów,

- z prywatyzacji majątku JST.

Wpływy ze sprzedaży i prywatyzacji majątku, które mają charakter jednorazowy, są wyrazem wyzbycia się trwałych dochodów możliwych do osiągnięcia w przyszłości i wiążą się z pozbyciem się tytułu prawa własności. Niewłaściwa lub nieodpowiedzialna gospodarka majątkiem w tym obszarze może prowadzić do zmniejszenia zaufania banków i ograniczenia JST możliwości pozyskiwania środków na rynkach finansowych. Zwraca na to uwagę m.in. M. Kosek-Wojnar (Dług lokalny...2007, s. 95), podkreślając, że władze samorządowe, korzystając z przychodów, ponoszą odpowiedzialność za wytworzenie w przyszłości dochodów, które umożliwią im spłatę oraz efektywną i racjonalną prywatyzację składników mienia JST.

Rola przychodów w finansowaniu rozwoju jest bezdyskusyjna i chociaż podlegają spłacie wraz z kosztami obsługi, trudno sobie wyobrazić dzisiaj funkcjonowanie samorządu, w szczególności finansowanie inwestycji, bez udziału kredytów czy pożyczek. Udział kredytów bankowych w kwocie długu ogółem JST wynosi nawet 93\% (por. Piszczek 2017). To pokazuje, jak ważną rolę w polityce finansowej JST odgrywają.

Odrębną grupą instrumentów, jakie mogą służyć finansowaniu rozwoju, są zobowiązania. W grupie tej wyróżniamy: zobowiązania, które wynikają z odroczonego systemu płatności, oraz umowy leasingowe, dzierżawy czy inne o podobnym charakterze.

Co do zobowiązań wobec dostawców dóbr i usług, zwanych często kredytem kupieckim, mogłyby one stać się znaczącym instrumentem finansowania długo- 
terminowego, są jednak w tej roli rzadko wykorzystywane, zaś samorządy mają tutaj niewielkie możliwości negocjacyjne. Niewątpliwie dużo atrakcyjniejsze dla samorządu ze względu na możliwości negocjacyjne są zobowiązania wobec instytucji finansowych (wobec banków i firm ubezpieczeniowych).

Ważnym źródłem wspierania rozwoju lokalnego czy regionalnego są różnego rodzaju fundusze specjalne. W działaniu samorządów istotne znaczenie mają regionalne i lokalne fundusze ochrony środowiska. Tworzone są one $\mathrm{z}$ opłat za korzystanie ze środowiska, pieniężnych kar administracyjnych, opłat podwyższonych za korzystanie ze środowiska, za szkody spowodowane oddziaływaniem na środowisko czy wpływów z opłat produktowych. Działania finansowane ze środków ochrony środowiska i gospodarki wodnej muszą przynieść określony efekt w tych obszarach w postaci ochrony środowiska.

Należy podkreślić, że ważną rolę w tworzeniu podstaw nowoczesnej polityki regionalnej i lokalnej w Polsce odgrywa z całą pewnością pomoc z budżetu Unii Europejskiej. Zgodnie z ustawą o finansach publicznych dochodami jednostek samorządu terytorialnego mogą być również środki pochodzące ze źródeł zagranicznych niepodlegające zwrotowi i środki pochodzące z budżetu Unii Europejskiej. Możliwość współfinansowania zadań inwestycyjnych ze środków UE została doskonale wykorzystana przez polskie samorządy i niewątpliwie wpłynęła pozytywnie na rozwój lokalny i regionalny (por. Surówka 2016).

Szczególną formą finansowania działań prorozwojowych jest partnerstwo publiczno-prywatne (PPP), które jest regulowane Ustawą z dnia 19 grudnia 2008 r. o partnerstwie publiczno-prywatnym. Istotą PPP jest współpraca i podział ryzyka przy wykonywaniu określonego projektu, tak aby rozkład zadań oraz ryzyka w przedsięwzięciu najlepiej wykorzystywał atuty każdego z uczestników projektu. Wówczas każda ze stron będzie w stanie wywiązać się $\mathrm{z}$ nałożonych zadań sprawniej niż druga. Podział zadań, odpowiedzialności i ryzyka w ramach PPP osiąga najbardziej efektywny ekonomicznie sposób tworzenia infrastruktury i dostarczania usług publicznych. Założeniem jest też to, że każda ze stron czerpie ze współpracy korzyści proporcjonalnie do swojego zaangażowania.

W Polsce instrument ten niestety jest wciąż dość rzadko stosowany. W okresie od stycznia 2009 r. do grudnia 2016 r. zawarto łącznie 112 umów. Ze wszystkich 470 wszczętych postępowań aż 297 zostało unieważnionych z różnych powodów. Obszarami, w których najczęściej stosowano formułę PPP, były: sport i turystyka, infrastruktura transportowa, efektywność energetyczna, infrastruktura zdrowotna czy gospodarka wodno-kanalizacyjna. Wartość zawartych umów - ok. 5,6 mld zł, w zestawieniu z kwotą wydatków inwestycyjnych w tym okresie - ok. 170 mld zł za lata 2012-2016, potwierdza tezę o niewielkim wykorzystaniu tego instrumentu do finansowania rozwoju (Analiza rynku... 2016, s. 31). 
Niewątpliwie mała popularność PPP w Polsce związana jest z tym, że samorządy, które są w tym wypadku najaktywniejszą stroną przy zawieraniu umów, od wielu lat $\mathrm{z}$ powodzeniem sięgają po środki unijne.

\section{Możliwości finansowania rozwoju przez samorząd w latach 2012-2016}

Podstawowe kategorie dochodowe i wydatkowe dla wszystkich JST w latach 2012-2014 (2012 r. = 100) wraz z ich dynamiką zmian, a także kwoty zobowiązań JST, wydatków inwestycyjnych, nadwyżki operacyjnej - podstawowej kategorii finansowej decydującej o możliwościach finansowania inwestycji przez samorząd, oraz spłaty zaciągniętych zobowiązań przedstawiono w tabelach 1-4.

Na podstawie danych dotyczących dochodów ogółem JST zaprezentowanych w tabeli 1 można stwierdzić, że średnie roczne tempo wzrostu/spadku (ŚRTW/S) dochodów ogółem wyniosło w badanym okresie 104,94\%, dochodów bieżących 106,69\%, a SRTW dla dochodów własnych ogółem kształtowało się na podobnym poziomie, tj. na poziomie $106,23 \%$. Najwyższe średnie roczne tempo wzrostu w latach 2012-2016 odnotowano dla kategorii dotacji celowych - wartość wskaźnika wyniosła 119,27\%. Na sytuację tę niewątpliwie wpłynęła wielkość środków, jaka została przekazana samorządom w związku z uruchomieniem programu Rodzina 500+. Kwota przekazywanych dotacji celowych w 2016 r. wzrosła o dodatkowe środki na ten program w wysokości 17,72 mld zł, co spowodowało wzrost dynamiki dotacji celowych między 2015 a 2016 r. o 169,5\%, zaś kategorii dotacji na zadania zlecone aż o 213,59\%. Jeśli chodzi o subwencję ogólną, ŚRTW w badanym okresie wyniosło 101,32\% (wzrost kwoty z 50,37 mld zł w 2012 r. do 53,06 mld zł w 2016 r.). W przypadku dochodów majątkowych wykazano spadek w badanym okresie - ŚRTS wynosi 91,66\%, mimo że pomiędzy 2013 a 2014 r. miał miejsce wzrost o ponad 11\%. Największy spadek odnotowano pomiędzy 2015 a 2016 r., z 22,96 mld zł do 13,02 mld zł., tj. o prawie 10 mld zł. Ten znaczący spadek dochodów majątkowych nie jest dobrym sygnałem z punktu widzenia finansowania rozwoju (wskaźnik dynamiki rok do roku wynosi 56,70\%).

W badanym okresie 2012-2016 na podobnym poziomie ŚRTS odnotowano dla dochodów majątkowych własnych $(91,99 \%)$. Zauważalny spadek ŚRTS jest również widoczny dla kategorii dotacji celowych na inwestycje - w badanym okresie wynosi on $91,80 \%$. Największy spadek odnotowano pomiędzy 2015 a 2016 r. - spadek z 17,13 mld zł do 8,34 mld zł, co oznacza, że wskaźnik dynamiki osiągnął bardzo niski poziom - 48,69\% (por. tabela 1).

Ciekawych wniosków dostarcza analiza tabeli 2. Prezentuje ona podstawowe dochody podatkowe gmin i miast na prawach powiatu. Ponieważ samorządy te 


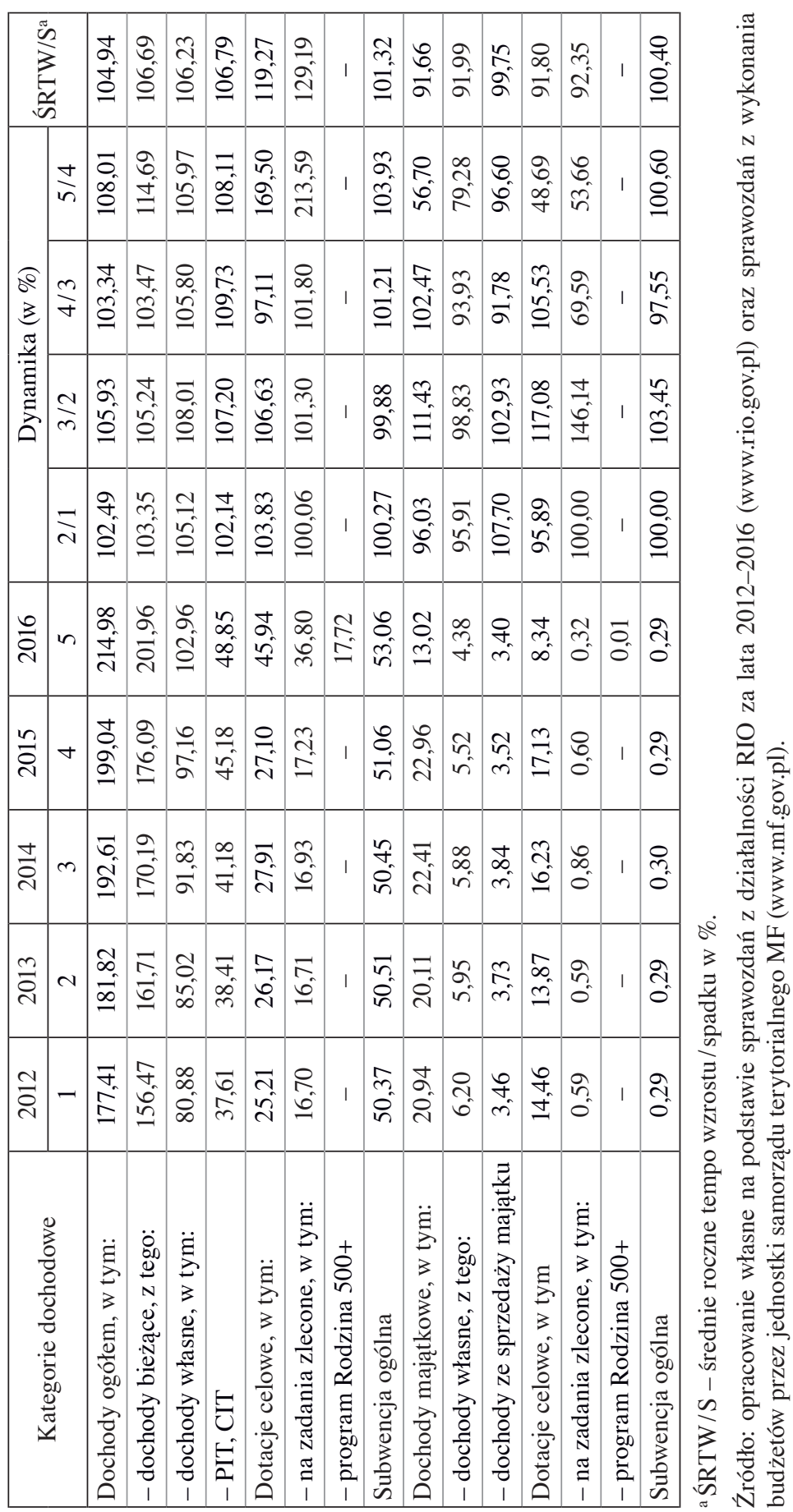


w kategorii podstawowej dla rozwoju - tj. inwestycji, obsługują prawie $75 \%$ ogółu wszystkich wydatków inwestycyjnych JST, warto przyjrzeć się, jak w ich przypadku kształtuje się polityka podatkowa. Przedstawione dane dotyczą lat 2014-2016. Jedną z głównych kategorii podatkowych są udziały w PIT i CIT. Analiza danych pozwala stwierdzić, że o ile ŚRTW tej kategorii dla wszystkich JST wynosi $106,79 \%$, o tyle w przypadku gmin i miast na prawach powiatu wynosi ponad $109 \%$. W strukturze podstawowych dochodów podatkowych ogółem wpływy z podatku PIT i CIT są bardzo wydajnym źródłem i wynoszą od 53,19\% do 55,60\% całości wpływów podatkowych w badanym okresie (por. tabela 2). Niezwykle wydajnym źródłem jest też podatek od nieruchomości, który w badanym okresie w strukturze podstawowych wpływów podatkowych stanowi średnio ok. $35 \%$ w każdym roku, przy czym ŚRTW tego podatku wykazuje najniższy po podatku rolnym wskaźnik wzrostu. Samorządy, udzielając ulg, zwolnień i umorzeń podatku, obniżyły bazę podatkową w badanym okresie o ponad 17 mld zł. Warto zwrócić uwagę, że z tego ponad 10 mld zł na skutek obniżenia podatków od nieruchomości. Dane tabeli 2 pokazują również ciekawą zależność pomiędzy wielkością obniżenia maksymalnych stawek podatkowych, ulg i zwolnień a kwotą wydatków na inwestycje tej grupy samorządów. Wskaźnik obniżenia podatków w poszczególnych latach w stosunku do kwoty inwestycji gmin i miast na prawach powiatu to wartość rosnąca od $15,92 \%$ do $21,51 \%$, co daje ŚRTW powyżej $116 \%$. W odniesieniu do wydatków ogółem wszystkich JST dla badanego okresu wzrost ŚRTW jest wyższy o kolejne 3 p.p. (119,3\%). Zasadny wydaje się wniosek dotyczący konieczności bardziej rozważnego prowadzenia polityki podatkowej w zakresie stosowania ulg czy zwolnień z podatku, a także obniżania maksymalnych stawek podatkowych, szczególnie w zakresie podatku od nieruchomości.

Tabela 2. Podstawowe dochody podatkowe gmin i miast na prawach powiatu w latach 2014-2016 (wykonanie w mld zł)

\begin{tabular}{|l|c|c|c|c|c|c|}
\hline \multirow{2}{*}{ Rodzaj dochodu } & 2014 & 2015 & 2016 & \multicolumn{2}{|c|}{ Dynamika (w \%) } & \multirow{2}{*}{ ŚRTW/Sa } \\
\cline { 2 - 6 } & 1 & 2 & 3 & $2 / 1$ & $3 / 2$ & \\
\hline $\begin{array}{l}\text { Podstawowe dochody podatkowe } \\
\text { ogółem, w tym: }\end{array}$ & 53,69 & 57,19 & 61,13 & 106,53 & 106,88 & 106,70 \\
\hline - PIT, CIT & 28,56 & 31,34 & 33,99 & 109,74 & 108,44 & 109,09 \\
\hline - podatek rolny & 1,65 & 1,60 & 1,53 & 97,24 & 95,54 & 96,39 \\
\hline - podatek od nieruchomości & 19,53 & 20,35 & 21,08 & 104,21 & 103,59 & 103,90 \\
\hline - podatek leśny & 0,20 & 0,22 & 0,30 & 111,00 & 137,18 & 124,09 \\
\hline $\begin{array}{l}\text { - podatek od środków } \\
\text { transportowych }\end{array}$ & 0,97 & 1,02 & 1,07 & 105,07 & 104,58 & 104,83 \\
\hline - pozostałe podatki i opłaty & 2,76 & 2,63 & 3,14 & 95,42 & 119,10 & 107,26 \\
\hline $\begin{array}{l}\text { CIT, PIT/podstawowe dochody } \\
\text { podatkowe ogółem (w \%) }\end{array}$ & 53,19 & 54,80 & 55,60 & 103,02 & 101,45 & 102,24 \\
\hline
\end{tabular}


cd, tabeli 2

\begin{tabular}{|l|c|c|c|c|c|c|}
\hline \multicolumn{1}{|c|}{ Rodzaj dochodu } & 2014 & 2015 & 2016 & \multicolumn{2}{|c|}{ Dynamika (w \%) } & ŚRT/Sa \\
\cline { 2 - 7 } & 1 & 2 & 3 & $2 / 1$ & $3 / 2$ & 97,38 \\
\hline $\begin{array}{l}\text { Podatek od nieruchomości/ } \\
\text { podstawowe dochody podatkowe } \\
\text { ogółem (w \%) }\end{array}$ & 36,38 & 35,59 & 34,49 & 97,83 & 96,92 & \\
\hline $\begin{array}{l}\text { Skutki decyzji podatkowych, } \\
\text { w tym: }\end{array}$ & 4,58 & 4,78 & 4,01 & 104,43 & 83,83 & 94,13 \\
\hline - podatek od nieruchomości & 3,42 & 3,73 & 3,07 & 109,17 & 82,11 & 95,64 \\
\hline $\begin{array}{l}\text { Wydatki inwestycyjne - JST } \\
\text { ogółem }\end{array}$ & 39,92 & 37,56 & 24,78 & 94,08 & 65,98 & 80,03 \\
\hline $\begin{array}{l}\text { Wydatki inwestycyjne - gminy } \\
\text { i miasta na prawach powiatu } \\
\text { (GiMnPP) }\end{array}$ & 28,77 & 26,65 & 18,64 & 92,63 & 69,94 & 81,28 \\
\hline $\begin{array}{l}\text { Wydatki inwestycyjne GiMnPP/ } \\
\text { inwestycje JST ogółem (w \%) }\end{array}$ & 72,07 & 70,96 & 75,22 & 98,46 & 106,00 & 102,23 \\
\hline $\begin{array}{l}\text { Obniżenie podatków jako \% } \\
\text { wydatków inwestycyjnych } \\
\text { GiMnPP }\end{array}$ & 15,92 & 17,95 & 21,51 & 112,74 & 119,87 & 116,31 \\
\hline $\begin{array}{l}\text { Obniżenie podatków jako \% } \\
\text { wydatków inwestycyjnych JST }\end{array}$ & 11,47 & 12,74 & 16,18 & 111,00 & 127,07 & 119,03 \\
\hline $\begin{array}{l}\text { Obniżenie podatków jako \% } \\
\text { podstawowych dochodów } \\
\text { podatkowych GiMnPP }\end{array}$ & 8,53 & 8,36 & 6,56 & 98,03 & 78,43 & 88,23 \\
\hline
\end{tabular}

a ŚRTW / S - średnie roczne tempo wzrostu/spadku w \%.

Źródło: opracowanie własne na podstawie sprawozdań z działalności RIO za lata 2012-2016 (www. rio.gov.pl) oraz sprawozdań z wykonania budżetów przez jednostki samorządu terytorialnego MF (www.mf.gov.pl).

Tendencje opisane powyżej dotyczące strony dochodowej JST, tj. struktury i poszczególnych źródeł dochodów, w szczególności istotnej pozycji dochodów własnych w dochodach ogółem, rosnących kwot dotacji celowych oraz rosnącego udziału dochodów bieżących w stosunku do majątkowych potwierdzają też dane zawarte w tabeli 3, która dodatkowo przedstawia również strukturę wydatków bieżących i majątkowych. Udział wydatków bieżących, które w strukturze budżetów JST wynosiły średnio ok. 80\%, zwiększył się w 2016 r. o 7\% (do 87\%). Tym samym utrzymujący się średnio na poziomie ok. $20 \%$ poziom wydatków inwestycyjnych w strukturze budżetów JST zmniejszył się do poziomu 12,5\% w 2016 r. Tendencję tę należy uznać za niekorzystną dla rozwoju lokalnego czy regionalnego.

Z punktu widzenia finansowania rozwoju ważne są nie tylko stabilne źródła dochodowe czy wydajna baza podatkowa, lecz również utrzymanie na najwyż- 
Tabela 3. Struktura głównych kategorii dochodów i wydatków JST w budżetach ogółem w latach 2012-2016 (w \%)

\begin{tabular}{|c|c|c|c|c|c|c|c|}
\hline Rok & $\begin{array}{c}\text { Dochody } \\
\text { własne }\end{array}$ & $\begin{array}{c}\text { Dotacje } \\
\text { celowe }\end{array}$ & $\begin{array}{c}\text { Subwencja } \\
\text { ogólna }\end{array}$ & $\begin{array}{c}\text { Dochody } \\
\text { bieżące }\end{array}$ & $\begin{array}{c}\text { Dochody } \\
\text { majątkowe }\end{array}$ & $\begin{array}{c}\text { Wydatki } \\
\text { bieżące }\end{array}$ & $\begin{array}{c}\text { Wydatki } \\
\text { majątkowe }\end{array}$ \\
\hline 2012 & 49,00 & 22,40 & 28,60 & 88,20 & 11,80 & 80,30 & 19,70 \\
\hline 2013 & 50,10 & 22,00 & 27,90 & 88,90 & 11,10 & 81,00 & 19,00 \\
\hline 2014 & 50,70 & 22,90 & 26,40 & 88,40 & 11,60 & 79,00 & 21,00 \\
\hline 2015 & 52,00 & 22,20 & 25,80 & 88,50 & 11,50 & 80,40 & 19,60 \\
\hline 2016 & 49,90 & 25,30 & 24,80 & 93,90 & 6,10 & 87,50 & 12,50 \\
\hline
\end{tabular}

Źródło: opracowanie własne na podstawie sprawozdań z działalności RIO za lata 2012-2016 (www. rio.gov.pl) oraz sprawozdań z wykonania budżetów przez jednostki samorządu terytorialnego MF (www.mf.gov.pl).

szym możliwym poziomie relacji pomiędzy dochodami bieżącymi a wydatkami bieżącymi. Relacja ta, opisana w ustawie o finansach publicznych jako nadwyżka operacyjna (art. 242), jest podstawową kategorią, którą posługują się również instytucje finansowe oceniające zdolność danej JST do spłacania zobowiązań.

Tabela 4 przedstawia podstawowe kategorie ekonomiczne w latach 2012-2016 dla wszystkich JST. Sa to: dochody ogółem, wydatki ogółem, dochody bieżące, wydatki bieżące, nadwyżka operacyjna, wydatki inwestycyjne, zobowiązania ogółem oraz ich relacje do dochodów czy wydatków wraz z ich dynamiką. Analiza danych pozwala na wysunięcie kilku wniosków ważnych z punktu widzenia możliwości finansowania rozwoju przez JST w kolejnych latach.

Po pierwsze ŚRTW dochodów ogółem i wydatków ogółem oraz dochodów bieżących i wydatków bieżących wykazują niewielką różnicę (ok. 1\%) na korzyść dochodów w obydwu przypadkach, co pozwala na wygenerowanie dodatniej różnicy - nadwyżki operacyjnej. Nadwyżkę operacyjną w badanym okresie charakteryzuje najwyższe ŚRTW $(115,47 \%)$, ale charakteryzuje też najwyższy spadek dynamiki - o prawie 10 p.p. Niepokojąca jest też tendencja odnotowana w 2016 r. w obszarze wydatków bieżących, których dynamika jest nieznacznie, ale jednak wyższa od dynamiki dochodów bieżących. Sytuacja ta wymaga monitorowania i rozważnego podejmowania decyzji w przyszłości co do zakresu finansowania zadań bieżących i ich standardu.

W badanym okresie daje się zauważyć spadkowa tendencja w wydatkach inwestycyjnych. ŚRTW dla tej kategorii wynosi $91,92 \%$, przy znacznym spadku dynamiki w 2016 r. do niespełna 66\%. Na sytuację, którą obserwujemy w polityce inwestycyjnej JST, składają się nie tylko decyzje w obszarze polityki dochodowej i wydatkowej JST, ale też konstrukcja często krytykowanego indywidualnego wskaźnika zadłużenia (Ustawa z dnia 27 sierpnia 2009 r. ..., art. 243), który ogranicza możliwości zaciągania zobowiązań przez JST, a tym samym finansowania 


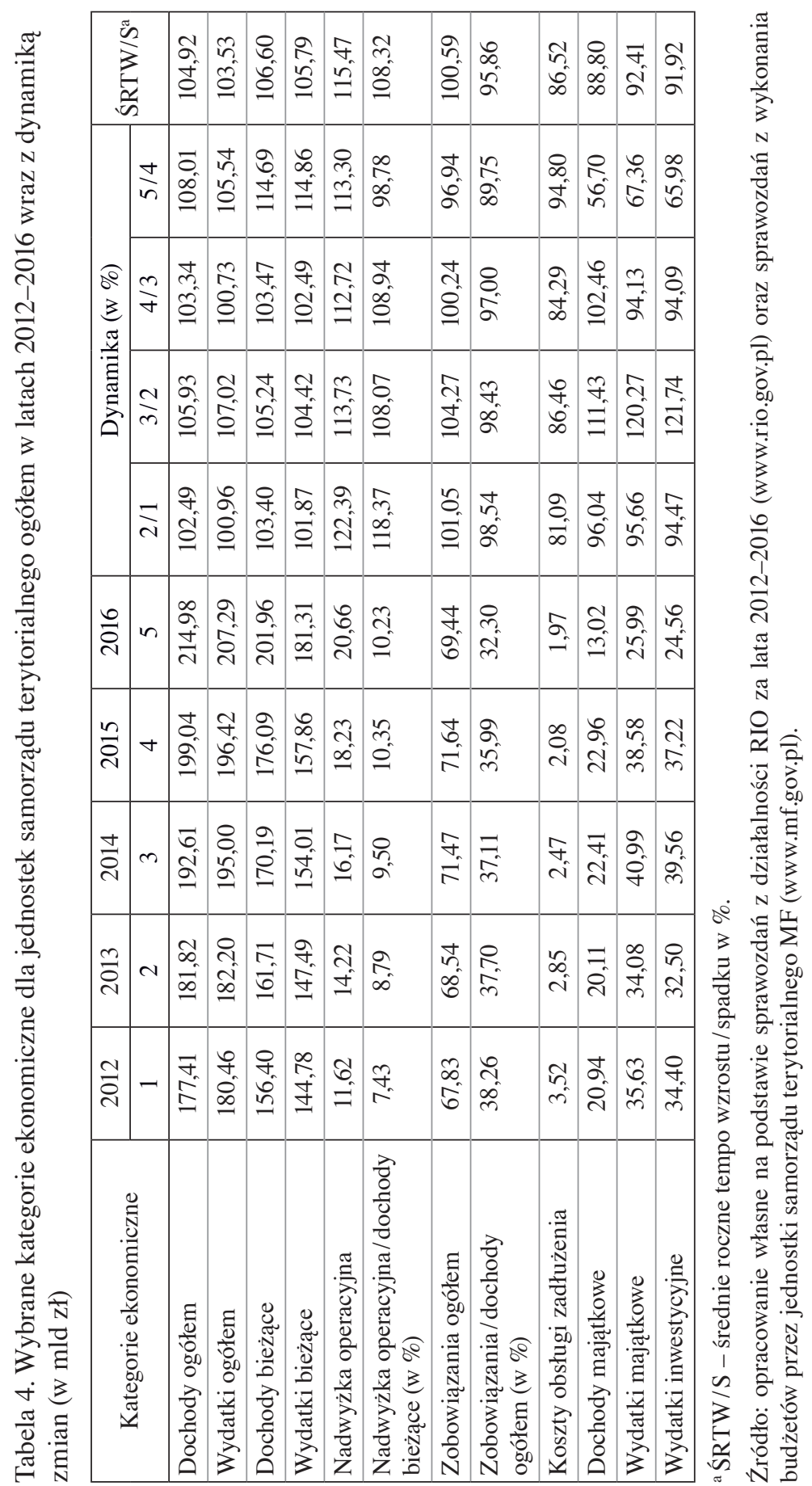


inwestycji rozwojowych i utrzymania ich dynamiki z lat poprzednich. Wydaje się, że bez zmian systemowych zmiana tej sytuacji na korzystniejszą dla JST nie jest możliwa (por. Sierak 2017, Surówka 2016, Jastrzębska 2016, Kornberger-Sokołowska 2015).

\section{Wnioski}

Rozwój lokalny czy regionalny jest priorytetem działań każdego samorządu. Dążenie do osiągania celów krótko- i długookresowych jest uwarunkowane zabezpieczeniem środków finansowych. JST mają ograniczone możliwości kształtowania strony dochodowej, mogą jednak racjonalnie korzystać z przyznanego im prawa do określania polityki finansowej, w tym podatkowej. Powinny dbać o to, aby źródła finansowania rozwoju cechowała stabilność i maksymalna wydajność. Zbyt niskie dochody własne przy rosnących kosztach zadań realizowanych przez JST są przyczyną spadku nadwyżki operacyjnej JST, a tym samym wpływają na obniżenie zdolności kredytowej JST, co może ograniczyć dostęp do zewnętrznych źródeł finansowania. Spadek nadwyżki operacyjnej dla wielu JST oznacza zmniejszenie planów rozwojowych lub całkowity brak możliwości ich realizacji. Aby temu przeciwdziałać, konieczne wydaje się podjęcie strategicznej decyzji w zakresie zmian systemowych, z uwzględnianiem podstawowych zasad samorządności, takich jak autonomia, samodzielność finansowa czy adekwatność środków finansowych do realizowanych zadań. Powinno to m.in. zaowocować decyzją o zwiększeniu dochodów JST i/lub zwiększeniu możliwości zadłużania się przez JST, jeżeli mają one pozostać odpowiedzialne za rozwój. Warto też rozważyć zmianę konstrukcji indywidualnego wskaźnika zadłużenia.

\section{Literatura}

Analiza rynku PPP za okres od 2009 r. do 31 grudnia 2016 r. (2016), red. B. Korbus, Instytut Partnerstwa Publiczno-Prywatnego, Warszawa

Chojna-Duch E., Kornberger-Sokołowska E. (1999), System dochodów jednostek samorzadu terytorialnego, ISS, Warszawa.

Dług lokalny w teorii i praktyce (2007), red. M. Kosek-Wojnar, Wydawnictwo Uniwersytetu Ekonomicznego w Krakowie, Kraków.

Domański T. (1999), Strategiczne planowanie rozwoju gospodarczego gminy, Agencja Rozwoju Komunalnego, Warszawa.

Filipiak B., Kogut M., Szewczuk A., Zioło M. (2005), Rozwój lokalny i regionalny. Uwarunkowania, finanse i procedury, DUO-TON, F.U.H.P., Szczecin.

Gałuszka K. (2005), Ocena efektywności finansowania rozwoju lokalnego (w:) Finanse samorzqdu terytorialnego. Zagadnienia wybrane, red. L. Patrzałek, Wydawnictwo Wyższej Szkoły Bankowej w Poznaniu, Poznań-Wrocław. 
Jastrzębska M. (2016), Nadmierne zadłużanie się jednostek samorzq̨du terytorialnego przyczyny, skutki, przeciwdziałanie, „Finanse Komunalne”, nr 6.

Kornberger-Sokołowska E. (2015), Wskaźnik zadłużenia a uwarunkowania funkcjonowania jednostek samorzqdu terytorialnego $w$ warunkach zmiennej koniunktury gospodarczej, „Finanse Komunalne”, nr 1-2.

Kożuch A. (2006), Instrumenty zarzq̨dzania rozwojem lokalnym, „Zeszyty Naukowe Akademii Rolniczej w Krakowie", nr 4.

Misiąg W. (2004), Budżet gminy dla praktyków, Wzory i przykłady uchwat, Municipium, Warszawa.

Perło D. (2004), Źródła finansowania rozwoju regionalnego, Wydawnictwo WSE w Białymstoku, Białystok.

Pietrzyk I. (2002), Polityka regionalna Unii Europejskiej i regiony w państwach członkowskich, Wydawnictwo Naukowe PWN, Warszawa.

Piszczek M. (2017), Zarzqdzanie długiem w jednostkach samorzqdu terytorialnego (w:) Sektor finansów publicznych a rozwój gospodarczy. Problemy i dylematy, red. M. Żukowski, Wydawnictwo KUL, Lublin.

Sierak J. (2017), Regionalne zróżnicowanie wielkości i dynamiki dochodów gmin i miast na prawach powiatu - analiza wskaźnikowa dla lat 2000-2014, „Finanse Komunalne", nr 1-2.

Surówka K. (2016), Pozyskiwanie środków unijnych a problem zadłużania się jednostek samorzqdu terytorialnego w okresie 2007-2013 - wnioski dla władz samorzqdowych $w$ nowej perspektywie, ,Finanse Komunalne”, nr 9.

Ustawa z dnia 5 czerwca 1998 r. o samorządzie wojewódzkim, Dz.U. nr 155, poz. 1014.

Ustawa z dnia 13 listopada 2003 r. o dochodach jednostek samorządu terytorialnego, Dz.U. poz. 1966.

Ustawa z dnia 19 grudnia 2008 r. o partnerstwie publiczno-prywatnym, Dz.U. 2009, nr 19, poz. 100 .

Ustawa z dnia 27 sierpnia 2009 r. o finansach publicznych, Dz.U. poz. 855, ze zm.

\section{Financing Development by Local Governments' Units}

(Abstract)

Ensuring funding is among the most important areas of management because it promotes development. It requires efficiency in day-to-day management of available resources, but also the ability to raise external financing at the lowest cost. Significant barriers to financing local government tasks prompt the need for alternative sources of investment financing in the form of loans or the issuing of securities. Changes have a significant impact on the financial situation of local governments, and thus a direct impact on funding opportunities for development. The subject matter of this article is the analysis of sources of financing development by local government. The research covers the years 2012-2016.

Keywords: local development, regional development, local government, sources of financing of the development. 